\title{
Relationships among Anxiety and Depression Levels with Sleep Quality and Insomnia Severity in Geriatric Patients with Depression
}

\section{Aslı Beşirli}

University of Health Sciences Turkey, Department of Psychiatry, Şişli Hamidiye Etfal Training and Research Hospital, İstanbul, Turkey

Submitted: 05.10.2019 Accepted: 14.02.2020

Correspondence: Aslı Beşirli, Sağlık Bilimleri Üniversitesi, Şişli Hamidiye Etfal Eğitim ve Araştırma Hastanesi, Psikiyatri Kliniği, İstanbul, Turkey

E-mail: abesirli2006@yahoo.com

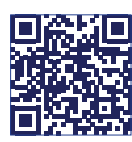

Keywords: Anxiety; depression; geriatric patient; sleep quality; insomnia severity.

This work is licensed under a Creative Commons Attribution-NonCommercial 4.0 International License.

\begin{abstract}
Objective: The prevalence of sleep problems increases with age. Both anxiety and depression symptoms can cause certain changes in sleep architecture. The aim of this study is to investigate the relationship of anxiety and depression levels with sleep quality and insomnia severity in geriatric patients with depression and concomitant anxiety symptoms.
\end{abstract}

Methods: Fifty-three patients aged 60 and over were included in the study. Geriatric Depression Scale (GDS), Beck Anxiety Inventory (BAI), Insomnia Severity Index (ISI), MiniMental State Examination (MMSE) and Pittsburgh Sleep Quality Index (PSQI) were applied to the patients.

Results: There was a positive and statistically significant relationships between the total GDS score and the mean PSQI Subjective sleep quality and Sleep latency scores, as well as between BAI and PSQI Subjective sleep quality, Sleep latency, Sleep disturbance, Daytime dysfunction and global PSQI score $(p=0.018 ; p=0.006 ; p=0.043 ; p=0.009 ; p=0.012 ; p=0.045$; $p=0.049$, respectively). There was positive and statistically significant relationships between total GDS, total ISI and ISI subscale scores, and there was positive and statistically significant relationships between BAI scores, total ISI, and ISI subscale scores $(p=0.002 ; p=0.002$; $p=0.001 ; p=0.006$, respectively).

Conclusion: This study showed that sleep disorders were closely associated with anxiety and depression levels in the geriatric patients with depression. The deterioration in sleep quality and the increase in insomnia severity associated with the aging process may increase the incidence of new depressive disorders, while current anxiety and depression symptoms may cause sleep disorders.

\section{INTRODUCTION}

Sleep can affect mental and physical health. ${ }^{[1]}$ The prevalence of sleep disorders increases in old age. Overall, $40 \%$ of people complain of sleep disorders; this rate increases to $63 \%$ of those aged $\geq 60$ years and to a whopping $67 \%$ of those who have had a prolonged stay in a nursing center. [2-4] An epidemiological study including participants aged $\geq 65$ years, found that more than $80 \%$ were experiencing at least one sleep problem and more than $50 \%$ had experienced at least one sleep problem throughout their lifetime. ${ }^{[5]}$

The sleep-wake cycle changes with age. Changes to the circadian rhythm cause altered sleep periods, in particular, an advanced phase in elderly individuals. ${ }^{[6]}$ The sleep durations in rapid eye movement sleep and stages 3 and 4 are reported to be shorter in elderly individuals. These changes, in conjunction with other age-related medical problems, lead to commonly encountered sleep issues. ${ }^{[7]}$

Sleep problems increase susceptibility to and manifest as a result of psychiatric disorders. ${ }^{[8,9]}$ Bidirectional relationships between sleep problems, depression and anxiety have been reported. ${ }^{[10,11]}$ Depression and anxiety disorders often coincide, and accompany general medical diseases, which affect their course and treatment. ${ }^{[12]}$ Both anxiety and depression can affect sleep architecture, whereas sleep disorders can increase the risk of depression and anxiety attacks by up to two-fold. ${ }^{[1,13]}$

Insomnia is a frequent sleep disorder in geriatric population, ${ }^{[14]}$ with a prevalence rate of $30 \%-48 \% .{ }^{[15,16]}$ Physical disorders such as pain, confusion and hypoxia and sleep disorders such as sleep apnea are potential causes of insomnia in the elderly population. ${ }^{[7]}$ Moreover, insomnia may be associated with psychiatric disorders such as 
anxiety ${ }^{[17]}$ and depression. ${ }^{[18]}$ Sleep deprivation can lead to mania or cause fatigue and irritability in depressed patients. In one study, higher levels of neuroticism and anxiety were found in severe insomniac patients compared to those without insomnia. ${ }^{[19]}$ It is determined in another study that $70 \%$ of older adults with depression had insomnia. ${ }^{[20]}$

There are many studies evaluating the relationships between sleep disorders and psychiatric conditions which have been conducted on patients with depression; however, fewer studies have been conducted on those with anxiety disorders.

This study aims to investigate the relationships among anxiety and depression levels with sleep quality and insomnia severity in geriatric patients with depression and concomitant anxiety symptoms who presented to a psychiatric outpatient clinic. The hypothesis of this study is: (a) geriatric patients with depression who have poor sleep quality and insomnia would have significantly higher depression and anxiety levels and (b) as insomnia severity increased, depression and anxiety levels would also increase.

\section{MATERIALS AND METHODS}

\section{Participants}

Of the 70 older adults who presented to the psychiatry outpatient clinic, the research population included 53 older participants who were aged $\geq 60$ years and met the research criteria and agreed to participate in the study. The participants were psychotropic-drug-naive during the study, literate, and did not have an alcohol or substance abuse problem within the past 6 months. Participants who had alcohol or substance abuse problems, schizophrenia or other psychotic disorders, were in a manic or hypomanic episode, had organic mental disorders, such as dementia and mental retardation according to the DSM$5^{[21]}$ criteria and had severe hearing or visual impairment were excluded. Nine older adults who had Mini Mental State Examinatin (MMSE) scores less than 24 and 8 older adults who did not agree to participate in the study were excluded. Participants were recruited randomly and consecutively to the study. The study protocol was approved by the local Ethics Committee (date: 04/17/2018, number: 985). The purpose and methods of the proposed research were explained to the participants and their written consent was obtained.

\section{Procedure and measures}

The demographic information (i.e., age, gender, marital status) was provided from the participants at baseline. The participants included in the study had a MMSE score $\geq 24$ and were diagnosed with major depressive disorder according to the DSM-5 ${ }^{[21]}$ criteria by a senior psychiatrist.

The Geriatric Depression Scale (GDS) which consists of a 30 -item questionnaire was used to assess depression.
[22] Each item includes a yes or no response. In this study, a GDS cut-off score of $\geq 14$ was applied. The validity and reliability of GDS scoring for Turkish population was affirmed by Ertan et al. ${ }^{[23]}$ (2000). The validity and reliability study of Turkish version revealed the cut-off score to be 13/14. In our study, the cut-off score for GDS was $\geq 14$ to indicate clinically relevant depression.

To assess anxiety level, The Beck Anxiety Inventory (BAI) ${ }^{[24]}$ was applied. The scale includes 21 items scored on Likert scales ranging between 0 to 3 . The validity and reliability of BAl scoring for Turkish population was affirmed by Ulusoy et al. ${ }^{[25]}$ (1996).

To assess the severity of insomnia, The Insomnia Severity Index (ISI) was applied. ISI score of 0-7 was defined as absence of clinically significant insomnia, ISI score of 8-14 was defined as subthreshold insomnia, ISI score of I5-2I was defined as moderate clinical insomnia and ISI score of 22-28 was defined as severe clinical insomnia. ${ }^{[26,27]}$ In this study, participants who scored $\geq 8$ on the ISI were classified into the 'insomnia group' and those who scored $<8$ were classified into the 'absence of insomnia group'. The validity and reliability of ISI scoring for Turkish population was affirmed by Boysan et al. ${ }^{[28]}$ (2010).

Cognition was assessed using the MMSE; a score less than 24 was accepted as impairment. ${ }^{[29]}$ The validity and reliability of MMSE scoring for Turkish population was affirmed by Güngen et al. ${ }^{[30]}(2002)$.

Subjective sleep quality was assessed using the Pittsburg Sleep Quality Index (PSQI). This is a 19-item questionnaire that consists of seven components: I) subjective sleep quality, 2) sleep onset latency, 3) sleep duration, 4) habitual sleep efficiency, 5) sleep disturbance, 6) use of sleep medication and 7) daytime functioning. The sum of seven component scores make up the global score that ranges from 0 to 21 . Higher scores reflect worse sleep. A standard cut-off greater than 5 indicates poor sleep quality. This cutoff has a sensitivity of $89.6 \%$ and specifity of $86.5 \%$ in distinguishing good sleepers from poor sleepers. ${ }^{[31]}$ The validity and reliability of PSQI scoring for Turkish population was affirmed by Agargun et al. ${ }^{[32]}$ (1996).

\section{Statistical analyses}

Statistical analyses were conducted by using the SPSS software version 15.0. Descriptive statistics were reported as numbers and percentages for categorical variables, and as means, standard deviations and minimum and maximum values for continuous variables. For data that were not normally distributed, comparisons were conducted using the Mann-Whitney $U$ test for two independent groups. Comparisons of continuous variables comprising $>2$ independent groups were conducted using one-way ANOVA or the Kruskal-Wallis test if they were normally or not normally distributed, respectively. Subgroup analyses were performed using the Tukey honestly significant difference test for parametric data and Mann-Whitney $U$ test for non-parametric data and were interpreted using the Bonferroni correction. 
Relationships between variables were analyzed using Spearman's correlation coefficient because the requirement for parametric testing was not provided. Ratio data were compared between groups using the chi-squared test. The statistical significance level (alpha) was set at $p<0.05$.

\section{RESULTS}

Sociodemographic characteristics of the patients

On average, participants had a mean \pm standard deviation age of $70.6 \pm 5.3$. Seventy-three point six percent of the participants were male and $26.4 \%$ were female. Sociodemographic characteristics of the patients are summarized in Table I.

\section{Correlations between PSQI subscales, GDS and BAI scores}

There was a positive and statistically significant relationship between total GDS scores and mean PSQI subjective sleep quality $(r=0.324 ; p=0.018)$ and sleep latency scores $(r=0.370 ; p=0.006)$, and between BAl scores and PSQI subjective sleep quality $(r=0.279 ; p=0.043)$, sleep latency $r=0.355 ; p=0.009)$, sleep disturbance $(r=0.343$; $p=0.012)$, daytime dysfunction $(r=0.277 ; p=0.045)$ and global $(r=0.272 ; p=0.049)$ scores (Table 2).

Sociodemographic characteristics of the patients with and without insomnia

There was a statistically significant difference between patients with and without insomnia in terms of the number of medical conditions $(p=0.035)$. The rate of having $\geq 2$ diseases was higher among patients with insomnia (Table 3 ).

Correlations between total ISI, ISI subscales, GDS and BAI scores

There was a positive and statistically significant relationship between total GDS scores and total ISI $(r=0.409$; $p=0.002)$ and ISI subscale $(r=0.4 \mid 4 ; p=0.002)$ scores, and between BAI scores and total ISI $(r=0.434 ; p=0.00 \mathrm{I})$ and ISI subscale $(r=0.375 ; p=0.006)$ scores (Table 4$)$.

Comparisons between ISI subscale scores and mean GDS and BAI scores

There was a statistically significant difference between ISI subscale scores and mean GDS $(p=0.014)$ and BAI $(p=0.015)$ scores (Table 5). Mean GDS $(p=0.008)$ and BAI $(p=0.009)$ scores among patients with severe insomnia were statistically significantly higher than those without insomnia (Table 6).

\section{DISCUSSION}

In this study, relationships between anxiety and depression levels with some sleep paremeters were detected in geriatric patients with depression.
Table I. Sociodemographic characteristics of patients

\begin{tabular}{|c|c|c|}
\hline & $\mathbf{n}$ & $\%$ \\
\hline \multicolumn{3}{|l|}{ Gender } \\
\hline Male & 39 & 73.6 \\
\hline Female & 14 & 26.4 \\
\hline Age, mean $\pm S D$ (min-max) & $70.6 \pm 5.3(6 \mid-86)$ & \\
\hline \multicolumn{3}{|l|}{ Age } \\
\hline $60-74$ & 43 & 81.1 \\
\hline$\geq 75$ & 10 & 18.9 \\
\hline \multicolumn{3}{|l|}{ Education } \\
\hline Reading and writing & 17 & 32.1 \\
\hline Primary school & 31 & 58.5 \\
\hline High school and above & 5 & 9.4 \\
\hline \multicolumn{3}{|l|}{ Marital status } \\
\hline Married & 34 & 64.2 \\
\hline Single & I & 1.9 \\
\hline Divorced/widowed & 18 & 34.0 \\
\hline \multicolumn{3}{|l|}{ Employment status } \\
\hline Homemaker & 28 & 52.8 \\
\hline Employee & 1 & 1.9 \\
\hline Retired & 24 & 45.3 \\
\hline \multicolumn{3}{|l|}{ Living arrangements } \\
\hline Alone & II & 20.8 \\
\hline With others & $4 I$ & 77.4 \\
\hline Nursing home & 1 & 1.9 \\
\hline \multicolumn{3}{|l|}{ Housing types } \\
\hline One or two rooms & 4 & 7.5 \\
\hline Three rooms & 37 & 69.8 \\
\hline Four or five rooms or bigger & 12 & 22.6 \\
\hline \multicolumn{3}{|l|}{ Medical conditions } \\
\hline None & I & 1.9 \\
\hline I & 5 & 9.4 \\
\hline 2 & 17 & 32.1 \\
\hline$>2$ & 30 & 56.6 \\
\hline \multicolumn{3}{|l|}{ Smoking status } \\
\hline Never & 35 & 66.0 \\
\hline Current & 2 & 3.8 \\
\hline Former & 16 & 30.2 \\
\hline BMI $\left(\mathrm{kg} / \mathrm{m}^{2}\right)$, mean $\pm \mathrm{SD}(\min -\max )$ & $27.9 \pm 4.2(20.2-41.8)$ & \\
\hline \multicolumn{3}{|l|}{ BMI } \\
\hline$<25$ & 10 & 18.9 \\
\hline $25.0-29.9$ & 31 & 58.5 \\
\hline$>=30$ & 12 & 22.6 \\
\hline Walks for exercise & 14 & 26.4 \\
\hline
\end{tabular}

BMI: Body mass index.

There was a positive relationships between depression scores and PSQI subscale scores reflecting subjective sleep quality and sleep latency. There are other studies with similar results in the literature. ${ }^{[33,34]}$ Maglione et al. ${ }^{[35]}$ conducted a study on older women and found a positive relationship between poorer subjective sleep quality and depression, consistent with the results of this study; by contrast, they did not report a relationship between the 
Table 2. Correlations between PSQI subscale scores and GDS and BAI scores

\begin{tabular}{lccccc}
\hline & \multicolumn{2}{c}{ GDS } & & & BAI \\
\cline { 2 - 5 } & rho & $\mathbf{p}$ & rho & p \\
\cline { 3 - 5 } PSQI & & & & 0.279 & 0.043 \\
Subjective sleep quality & 0.324 & 0.018 & 0.355 & 0.009 \\
Sleep latency & 0.370 & 0.006 & 0.062 & 0.659 \\
Sleep duration & 0.131 & 0.349 & 0.099 & 0.481 \\
Habitual sleep efficiency & 0.170 & 0.223 & 0.343 & 0.012 \\
Sleep disturbance & 0.047 & 0.739 & 0.053 & 0.704 \\
Use of sleep medication & -0.097 & 0.491 & 0.277 & 0.045 \\
Daytime dysfunction & 0.244 & 0.078 & 0.272 & 0.049 \\
Global score & 0.230 & 0.098 & & \\
\hline
\end{tabular}

PSQI: Pittsburgh Sleep Quality Index; GDS: Geriatric Depression Scale; BAI: Beck Anxiety Inventory.

level of depression and prolonged sleep latency. Orhan et al. ${ }^{[36]}$ conducted a study in Turkey, which included older patients living in a nursing home and reported similar results in this study. Another study conducted on an elderly Asian population detected no relationships between sleep quality, sleep latency and GDS, differentness from the results of this study. ${ }^{[3]}$

It was reported a positive relationship between anxiety scores and subjective sleep quality, sleep disturbance, daytime dysfunction, sleep latency and global PSQI scores in this study. Similarly, Yu et al. ${ }^{[37]}$ detected a relationship between anxiety scores and global PSQI, sleep latency, sleep disturbance and subjective sleep quality scores in an elderly population, but they detected no relationship between anxiety scores and daytime dysfunction. Similarly Gould et al. ${ }^{[38]}$ showed that anxiety symptoms might be associated with poor sleep quality in old adults.

There was no relationships between anxiety scores and habitual sleep efficiency, use of sleep medication and sleep duration which is similar to the findings of $Y u$ et al. ${ }^{[37]}$ Chang et al. ${ }^{[33]}$ detected a relationship between anxiety and all PSQI subscale scores, which is different to a certain extent from the current findings.

Although some studies in the literature showed that short sleep duration was related to anxiety and depression levels, ${ }^{[3,39]}$ there was no such relationship in this study. Mason et al. ${ }^{[40]}$ demonstrated that symptoms of anxiety and depression were ameliorated after treatment, but there was no change in sleep duration. Therefore, it has been hypothesized that sleep duration could not be associated with depression and anxiety. ${ }^{[37]}$ According to this study, there was no relationship between anxiety or depression levels and habitual sleep efficiency and use of sleep medication, in contrast with the results obtained by Chang et al. ${ }^{[33]}$ These different results could be associated with regional and aetiological differences and smaller sample size of this study compared with other studies in the literature. In one study, it was found that sleep disturbances in latelife depression are related to the severity of depression and older depressive patients with sleep problems had more anxiety and depression symptoms which is consistent with the results of this study. ${ }^{[4 I]}$

This study demonstrated that patients with insomnia had a higher number of medical issues. Similarly, other studies have reported that multiple medical problems were associated with insomnia. ${ }^{[42,43]}$ By contrast, there was no relationship between other sociodemographic factors and insomnia in this study.

There was a positive correlation between the severity of insomnia and anxiety and depression scores in this study. Patients with severe insomnia had higher GDS and BAI scores compared to those without insomnia. In parallel, it was detected that patients with depression had higher rates of moderate and severe insomnia. There are many studies that provided similar results to this study. For example, in one study, elderly patients with insomnia had higher levels of anxiety and depression compared to those without insomnia. ${ }^{[4]}$ Another study conducted on patients older than $\mathbf{8 0}$ years detected that insomnia severity was associated with various medical problems including depression and anxiety. ${ }^{[7]}$ Dragioti et al. ${ }^{[14]}$ observed in an elderly sample that the incidence of depression and anxiety was higher in patients with subthreshold, moderate and severe insomnia than those without insomnia. Similar to the results of this study, Farazdaq et al. ${ }^{[44]}$ showed that depression increases the risk of insomnia in old age.

In another study, elderly patients with generalized anxiety disorder with depression or without depression, exhibited a higher insomnia severity which is consistent with the findings of this study; by contrast, no difference was found between patients with generalized anxiety disorder only and patients with comorbid depression in terms of sleep disorders. ${ }^{[45]}$

The impact of insomnia on depression and anxiety are explained by the diathesis-stress model. In this model, stress triggered by an insomnia attack could aggravate or induce the development of recurrent depression or anxiety. Time spent awake in bed at night might induce negative thoughts about the past or concerns about the future, including responsibilities in the upcoming day, thereby 
Table 3. Sociodemographic characteristics of patients with and without insomnia

\begin{tabular}{|c|c|c|c|c|c|}
\hline & \multicolumn{2}{|c|}{ Patients with insomnia } & \multicolumn{2}{|c|}{ Patients without insomnia } & \multirow[b]{2}{*}{$\mathbf{p}$} \\
\hline & $\mathbf{n}$ & $\%$ & $\mathbf{n}$ & $\%$ & \\
\hline \multicolumn{6}{|l|}{ Gender } \\
\hline Male & 34 & 73.9 & 5 & 71.4 & 1.000 \\
\hline Female & 12 & 26.1 & 2 & 28.6 & \\
\hline \multicolumn{6}{|l|}{ Age } \\
\hline $60-74$ & 37 & 80.4 & 6 & 85.7 & 1.000 \\
\hline$\geq 75$ & 9 & 19.6 & 1 & 14.3 & \\
\hline \multicolumn{6}{|l|}{ Education } \\
\hline Reading and writing & 14 & 30.4 & 3 & 42.9 & 0.850 \\
\hline Primary school & 27 & 58.7 & 4 & 57.1 & \\
\hline High school and above & 5 & 10.9 & 0 & 0.0 & \\
\hline \multicolumn{6}{|l|}{ Marital status } \\
\hline Married & 29 & 63.0 & 5 & 71.4 & 1.000 \\
\hline Single & 1 & 2.2 & 0 & 0.0 & \\
\hline Divorced/widowed & 16 & 34.8 & 2 & 28.6 & \\
\hline \multicolumn{6}{|l|}{ Employment status } \\
\hline Homemaker & 24 & 52.2 & 4 & 57.1 & 1.000 \\
\hline Employee & I & 2.2 & 0 & 0.0 & \\
\hline Retired & 21 & 45.7 & 3 & 42.9 & \\
\hline \multicolumn{6}{|l|}{ Living arrangements } \\
\hline Alone & 8 & 17.4 & 3 & 42.9 & 0.265 \\
\hline With others & 37 & 80.4 & 4 & 57.1 & \\
\hline Nursing home & I & 2.2 & 0 & 0.0 & \\
\hline \multicolumn{6}{|l|}{ Housing types } \\
\hline I or 2 rooms & 4 & 8.7 & 0 & 0.0 & 1.000 \\
\hline 3 rooms & 32 & 69.6 & 5 & 71.4 & \\
\hline 4 or 5 rooms or bigger & 10 & 21.7 & 2 & 28.6 & \\
\hline \multicolumn{6}{|l|}{ Medical conditions } \\
\hline None & 0 & 0.0 & 1 & 14.3 & 0.035 \\
\hline 1 & 3 & 6.5 & 2 & 28.6 & \\
\hline 2 & 16 & 34.8 & I & 14.3 & \\
\hline$>2$ & 27 & 58.7 & 3 & 42.9 & \\
\hline \multicolumn{6}{|l|}{ Smoking status } \\
\hline Never & 30 & 65.2 & 5 & 71.4 & 1.000 \\
\hline Current & 2 & 4.3 & 0 & 0.0 & \\
\hline Former & 14 & 30.4 & 2 & 28.6 & \\
\hline \multicolumn{6}{|l|}{ BMI $\left(\mathrm{kg} / \mathrm{m}^{2}\right)$} \\
\hline$<25$ & 8 & 17.4 & 2 & 28.6 & 0.729 \\
\hline $25.0-29.9$ & 27 & 58.7 & 4 & 57.1 & \\
\hline$>=30$ & 11 & 23.9 & I & 14.3 & \\
\hline \multicolumn{6}{|l|}{ Walks for exercise } \\
\hline Yes & 12 & 26.1 & 2 & 28,6 & 1.000 \\
\hline No & 34 & 73.9 & 5 & 71.4 & \\
\hline
\end{tabular}

BMI: Body mass index.

causing depression and anxiety. Conversely, daytime ruminations about depression and anxiety (e.g. depressive relationships, negative thoughts about the past or responsibilities in the upcoming day) could enhance mental and physiological arousal, leading to insomnia. ${ }^{[46]}$

The main limitations of this study are: First, this was a single-center study with a small sample. Second, self-re- ported data were obtained and objective sleep measurements (such as polysomnography) could not be performed which could have affected the outcomes reflecting sleep. Third, chronic diseases such as asthma, obstructive sleep apnea, chronic obstructive pulmonary disease and heart diseases could have affected the results of sleep quality and insomnia severity. 
Table 4. Correlations between total ISI score, ISI subscales and GDS, BAI scores

\begin{tabular}{lccccc}
\hline & \multicolumn{2}{c}{ GDS } & & \multicolumn{1}{c}{ BAI } & \\
\cline { 2 - 5 } & rho & p & rho & p \\
\hline Total ISI score & 0.409 & 0.002 & 0.434 & 0.001 \\
ISI Subscales scores & 0.414 & 0.002 & 0.375 & 0.006 \\
\hline
\end{tabular}

GDS: Geriatric Depression Scale; BAI: Beck Anxiety Inventory; ISI: Insomnia Severity Index.

Table 5. The comparison of mean GDS and BAI scores with ISI subscales

\begin{tabular}{|c|c|c|c|c|}
\hline & \multicolumn{2}{|c|}{ GDS } & \multicolumn{2}{|c|}{ BAI } \\
\hline & Mean $\pm S D$ & Median & Mean $\pm S D$ & Median \\
\hline \multicolumn{5}{|l|}{ ISI Subscales } \\
\hline Absence of insomia & $8.8 \pm 5.0$ & 7 & $9.0 \pm 9.5$ & 7 \\
\hline Subthreshold insomnia & $14.0 \pm 7.3$ & 14 & $17.5 \pm 11.9$ & 17.5 \\
\hline Moderate insomnia & $14.2 \pm 6.6$ & 13 & $17.8 \pm 12.8$ & 17 \\
\hline Severe insomnia & $19.5 \pm 7.6$ & 20 & $28.4 \pm 14.8$ & 26 \\
\hline $\mathrm{p}$-value & \multicolumn{2}{|c|}{0.014} & \multicolumn{2}{|c|}{0.015} \\
\hline
\end{tabular}

Table 6. Comparisons between ISI subcale scores and mean GDS and BAI scores

\begin{tabular}{ccc}
\hline & ISI subscales & p \\
\hline GDS & & \\
Absence of insomia & Subthreshold insomnia & 0.315 \\
& Moderate insomnia & 0.243 \\
& Severe insomnia & 0.008 \\
Subthreshold insomnia & Moderate insomnia & 1.000 \\
& Severe insomnia & 0.207 \\
Moderate insomnia & Severe insomnia & 0.176 \\
BAI & & \\
Absence of insomia & Subthreshold insomnia & 0.431 \\
& Moderate insomnia & 0.349 \\
Subthreshold insomnia & Severe insomnia & 0.009 \\
& Moderate insomnia & 1.000 \\
Moderate insomnia & Severe insomnia & 0.154 \\
& Severe insomnia & 0.128 \\
\hline
\end{tabular}

BAI: Beck Anxiety Inventory; GDS: Geriatric Depression Scale; ISI: Insomnia Severity Index.

In conclusion, this study demonstrated that sleep disorders were closely related to anxiety and depression levels in the geriatric population. The deterioration in sleep quality and increase in the severity insomnia associated with the ageing process may increase the incidence of new depressive disorders, whereas current anxiety and depression symptoms may cause sleep disorders. Considering that the geriatric population is gradually expanding, sleep disorders are becoming more prevalent in this group and should be evaluated in conjunction with psychiatric disorders. Further studies with a larger sample size are warranted to obtain more robust evidence among this patient group and to develop treatment approaches.

\section{Ethics Committee Approval}

The study protocol was approved by the local Ethics Committee (date: 04/17/2018, number: 985).

Informed Consent

Prospective study.

Peer-review

Internally peer-reviewed.

Conflict of Interest

None declared.

\section{REFERENCES}

1. Cinosi E, Di Iorio G, Acciavatti T, Cornelio M, Vellante F, De Risio L, et al. Sleep disturbances in eating disorders: a review. Clin Ter 2011;162:e195-202.

2. Almeida OP, Pfaff JJ. Sleep complaints among older general practice patients: association with depression. Br J Gen Pract 2005;55:864-6.

3. Haesler EJ. Effectiveness of strategies to manage sleep in residents of aged care facilities. JBI Libr Syst Rev 2004;2:1-107. [CrossRef]

4. Simon GE, VonKorff M. Prevalence, burden, and treatment of insomnia in primary care. Am J Psychiatry 1997;154:1417-23. [CrossRef]

5. Foley DJ, Monjan AA, Brown SL, Simonsick EM, Wallace RB, Blazer DG. Sleep complaints among elderly persons: an epidemiologic study of three communities. Sleep 1995;18:425-32. [CrossRef]

6. Neikrug AB, Ancoli-Israel S. Sleep disorders in the older adult - a mini-review. Gerontology 2010;56:181-9. [CrossRef]

7. Jensen E, Dehlin O, Hagberg B, Samuelsson G, Svensson T. Insomnia in an 80-year-old population: relationship to medical, psychological and social factors. J Sleep Res 1998;7:183-9. [CrossRef]

8. Asarnow LD, Soehner AM, Harvey AG. Circadian rhythms and psychiatric illness. Curr Opin Psychiatry 2013;26:566-71. [CrossRef]

9. Ford DE, Kamerow DB. Epidemiologic study of sleep disturbances and psychiatric disorders. An opportunity for prevention?. JAMA 1989;262:1479-84. [CrossRef] 
10. Palagini L, Baglioni C, Ciapparelli A, Gemignani A, Riemann D. REM sleep dysregulation in depression: state of the art. Sleep Med Rev 2013;17:377-90. [CrossRef]

11. Jansson-Fröjmark M, Lindblom K. A bidirectional relationship between anxiety and depression, and insomnia? A prospective study in the general population.J Psychosom Res 2008;64:443-9. [CrossRef]

12. Karamustafalıoğlu O, Yumrukçal H. Depression and anxiety disorders. Med Bull Sisli Etfal Hosp 2011;45:65-74.

13. Baglioni C, Battagliese G, Feige B, Spiegelhalder K, Nissen C, Voderholzer $\mathrm{U}$, et al. Insomnia as a predictor of depression: a meta-analytic evaluation of longitudinal epidemiological studies. J Affect Disord 2011;135:10-9. [CrossRef]

14. Dragioti E, Levin LÅ, Bernfort L, Larsson B, Gerdle B. Insomnia severity and its relationship with demographics, pain features, anxiety, and depression in older adults with and without pain: cross-sectional population-based results from the PainS65+ cohort. Ann Gen Psychiatry 2017;16:15. [CrossRef]

15. Ohayon MM. Epidemiology of insomnia: what we know and what we still need to learn. Sleep Med Rev 2002;6:97-111. [CrossRef]

16. Hillman DR, Murphy AS, Pezzullo L. The economic cost of sleep disorders. Sleep 2006;29:299-305. [CrossRef]

17. Morgan K, Dallosso H, Ebrahim S, Arie T, Fentem PH. Characteristics of subjective insomnia in the elderly living at home. Age Ageing 1988;17:1-7. [CrossRef]

18. Rosen J, Reynolds CF 3rd, Yeager AL, Houck PR, Hurwitz LF. Sleep disturbances in survivors of the Nazi Holocaust. Am J Psychiatry 1991;148:62-6. [CrossRef]

19. Morgan K, Healey DW, Healey PJ. Factors influencing persistent subjective insomnia in old age: a follow-up study of good and poor sleepers aged 65 to 74. Age Ageing 1989;18:117-22. [CrossRef]

20. Brabbins CJ, Dewey ME, Copeland JRM, Davidson IA, McWilliam C, Saunders P, et al. Insomnia in the elderly : Prevalence, gender differences and relationships with morbidity and mortality. Int J Geriatr Psychiatr 1993;8:473-80. [CrossRef]

21. American Psychiatric Association. Diagnostic and Statistical Manual of Mental Disorders, 5th ed. Arlington: American Psychiatric Publishing,; 2013. [CrossRef]

22. Yesavage JA, Brink TL, Rose TL, Lum O, Huang V, Adey M, et al. Development and validation of a geriatric depression screening scale: a preliminary report. J Psychiatr Res 1982-1983;17:37-49. [CrossRef]

23. Ertan T, Eker E. Reliability, validity, and factor structure of the geriatric depression scale in Turkish elderly: are there different factor structures for different cultures?. Int Psychogeriatr 2000;12:163-72.

24. Beck AT, Epstein N, Brown G, Steer RA. An inventory for measuring clinical anxiety: psychometric properties. J Consult Clin Psychol 1988;56:893-7. [CrossRef]

25. Ulusoy M, Şahin NH, Erkmen H. Turkish version of the Beck Anxiety Inventory: Psychometric properties. J Cognit Psychother 1996;12:163-72.

26. Morin CM, Belleville G, Bélanger L, Ivers H. The Insomnia Severity Index: psychometric indicators to detect insomnia cases and evaluate treatment response. Sleep 2011;34:601-8. [CrossRef]

27. Bastien $\mathrm{CH}$, Vallières A, Morin CM. Validation of the Insomnia Severity Index as an outcome measure for insomnia research. Sleep Med 2001;2:297-307. [CrossRef]

28. Boysan M, Gulec M, Besiroglu L, Kalafat T. Psychometric properties of the Insomnia Severity Index in Turkish sample. Anatolian Journal of Psychiatry 2010;11:248-52.
29. Folstein MF, Folstein SE, McHugh PR. "Mini-mental state". A practical method for grading the cognitive state of patients for the clinician. J Psychiatr Res 1975;12:189-98. [CrossRef]

30. Güngen C, Ertan T, Eker E, Yaşar R, Engin F. Reliability and validity of the standardized Mini Mental State Examination in the diagnosis of mild dementia in Turkish population. Turk Psikiyatri Derg 2002;13:273-81.

31. Buysse DJ, Reynolds CF 3rd, Monk TH, Berman SR, Kupfer DJ. The Pittsburgh Sleep Quality Index: a new instrument for psychiatric practice and research. Psychiatry Res 1989;28:193-213. [CrossRef]

32. Agargun MY, Kara H, Anlar O. The validity and reliability of the Pitssburgh Sleep Quality Index. Turk Psikiyatri Derg 1996;7:10715.

33. Chang KJ, Son SJ, Lee Y, Back JH, Lee KS, Lee SJ, et al. Perceived sleep quality is associated with depression in a Korean elderly population. Arch Gerontol Geriatr 2014;59:468-73. [CrossRef]

34. Paudel ML, Taylor BC, Diem SJ, Stone KL, Ancoli-Israel S, Redline $\mathrm{S}$, et al; Osteoporotic Fractures in Men Study Group. Association between depressive symptoms and sleep disturbances in communitydwelling older men. J Am Geriatr Soc 2008;56:1228-35. [CrossRef]

35. Maglione JE, Ancoli-Israel S, Peters KW, Paudel ML, Yaffe K, Ensrud $\mathrm{KE}$, et al. Depressive symptoms and subjective and objective sleep in community-dwelling older women.J Am Geriatr Soc 2012;60:635-43.

36. Orhan FO, Tuncel D, Taş F, Demirci N, Ozer A, Karaaslan MF. Relationship between sleep quality and depression among elderly nursing home residents in Turkey. Sleep Breath 2012;16:1059-67. [CrossRef]

37. Yu J, Rawtaer I, Fam J, Jiang MJ, Feng L, Kua EH, et al. Sleep correlates of depression and anxiety in an elderly Asian population. Psychogeriatrics 2016;16:191-5. [CrossRef]

38. Gould CE, Spira AP, Liou-Johnson V, Cassidy-Eagle E, Kawai M, Mashal N, et al. Association of Anxiety Symptom Clusters with Sleep Quality and Daytime Sleepiness. J Gerontol B Psychol Sci Soc Sci 2018;73:413-20. [CrossRef]

39. Park S, Cho MJ, Chang SM, Bae JN, Jeon HJ, Cho SJ, et al. Relationships of sleep duration with sociodemographic and health-related factors, psychiatric disorders and sleep disturbances in a community sample of Korean adults. J Sleep Res 2010;19:567-77. [CrossRef]

40. Mason EC, Harvey AG. Insomnia before and after treatment for anxiety and depression. J Affect Disord 2014;168:415-21. [CrossRef]

41. Peters van Neijenhof RJG, van Duijn E, Comijs HC, van den Berg JF, de Waal MWM, Oude Voshaar RC, et al. Correlates of sleep disturbances in depressed older persons: the Netherlands study of depression in older persons (NESDO). Aging Ment Health 2018;22:233-8.

42. Budhiraja R, Roth T, Hudgel DW, Budhiraja P, Drake CL. Prevalence and polysomnographic correlates of insomnia comorbid with medical disorders. Sleep 2011;34:859-67. [CrossRef]

43. Ayoub AI, Attia M, El Kady HM, Ashour A. Insomnia among community dwelling elderly in Alexandria, Egypt. J Egypt Public Health Assoc 2014;89:136-42. [CrossRef]

44. Farazdaq H, Andrades M, Nanji K. Insomnia and its correlates among elderly patients presenting to family medicine clinics at an academic center. Malays Fam Physician 2018;13:12-9.

45. Brenes GA, Miller ME, Stanley MA, Williamson JD, Knudson M, McCall WV. Insomnia in older adults with generalized anxiety disorder. Am J Geriatr Psychiatry 2009;17:465-72. [CrossRef]

46. Monroe SM, Simons AD. Diathesis-stress theories in the context of life stress research: implications for the depressive disorders. Psychol Bull 1991;110:406-25. [CrossRef] 
Geriatrik Depresyon Hastalarında Anksiyete ve Depresyon Düzeyleri ile Uyku Kalitesi ve Uykusuzluk Şiddeti Arasındaki İlişki

Amaç: Uyku problemlerinin sıklı̆̆ı yaşla birlikte artmaktadır. Hem anksiyete hem de depresyon belirtileri uyku mimarisini etkileyebilmektedir. Bu çalışmanın amacı, psikiyatri polikliniğine başvuran anksiyete belirtilerinin eşlik ettiği geriatrik depresyon hastalarında anksiyete ve depresyon düzeyleri ile uyku kalitesi ve uykusuzluk şiddeti arasındaki ilişkinin incelenmesidir.

Gereç ve Yöntem: 60 yaş ve üzeri 53 hasta çalışmaya dahil edildi. Hastalara Geriatrik Depresyon Ölçeği (GDÖ), Beck Anksiyete Ölçeği (BAÖ), Uykusuzluk Şiddeti İndeksi (UŞi), Kısa Akıl Muayenesi (KAM) ve Pittsburg Uyku Kalitesi İndeksi (PUKi) uygulandı.

Bulgular: Total GDÖ skoru ile PUKi öznel uyku kalitesi $(p=0.018)$ ve uyku latansı $(p=0.006)$, alt skorları arasında pozitif yönde ve BAÖ ile PUKi öznel uyku kalitesi ( $p=0.043)$, uyku latansı $(p=0.009)$, uyku bozukluğu $(p=0.012)$, gündüz işlev bozukluğu $(p=0.045)$ ve global $P U K i$ $(p=0.049)$ skorları arasında pozitif yönde istatistiksel olarak anlamlı ilişkili saptandı. Total GDÖ skoru ile total ISI skoru $(p=0.002)$ ve ISI alt ölçekleri arasında $(p=0.002)$ ve BAÖ skoru ile total ISI $(p=0.00 I)$ ve ISI alt ölçekleri $(p=0.006)$ arasında ile pozitif yönde istatistiksel olarak anlamlı ilişkili saptandı.

Sonuç: Bu çalışmada, geriatrik depresyon hastalarında uyku bozukluklarının anksiyete ve depresyon düzeyi ile yakından ilişkili olduğu gösterilmiştir. Yaşlanma süreciyle birlikte ortaya çıkan uyku kalitesindeki bozulma ve insomnia şiddetindeki artış yeni oluşan depresif bozukluk görülme sıklığı ve şiddetini artırabilirken, mevcut anksiyete ve depresyon belirtileri de uyku bozukluklarına sebep olabilmektedir.

Anahtar Sözcükler: Anksiyete; depresyon; geriatrik hasta; uyku kalitesi; uykusuzluk şiddeti. 